\title{
Charakterystyka finansowa przedsiębiorstw hazardu - pomiar statystyczny
}

\section{Wstęp}

Działalność w zakresie organizowania oraz urządzania gier i zakładów wzajemnych to bardzo specyficzny rodzaj branży gospodarczej. $Z$ jednej strony dostarcza rozrywki i uprzyjemnia wolny czas obywatelom, z drugiej ma niemały wpływ na dochody budżetu państwa. W 2013 roku wpływy z podatku od gier wyniosły łącznie blisko 1,4 mld zł. Dodatkowo istotną kwestią związaną z działalnością hazardową jest problem uzależnienia od hazardu. To wszystko w połączeniu z innymi patologiami, które mogą towarzyszyć tej działalności skłania do zastanowienia się nad specyfiką branży oraz poziomem ekonomicznym jej rozwoju. W szczególności analizy wymaga okres ostatnich kilku lat obowiązywania ustawy z dnia 29 lipca 1992 roku o grach i zakładach wzajemnych, w których byliśmy świadkami tzw. afery hazardowej, co w rezultacie spowodowało wprowadzenie nowych regulacji, tj. ustawy z dnia 19 listopada 2009 roku o grach hazardowych.

\section{Cel i metody badań}

Celem artykułu było przedstawienie na podstawie pomiaru i analizy statystycznej istotnych różnic finansowych między branżą niskiego i wysokiego hazardu, jak również przeprowadzenie analizy sytuacji finansowej przedsiębiorstw świadczących gry na automatach o niskich wygranych.

Badaniem objęto wszystkie podmioty prowadzące działalność na rynku gier i zakładów wzajemnych w latach 2006-2008. Dla opisu zróżnicowania między badanymi grupami przedsiębiorstw podzielono je na dwa podzbiory przedsiębiorstw świadczących usługi, tj. wysokiego (grupa 1) i niskiego hazardu (grupa 
2). Celem podzielenia zbioru danych na dwie grupy była analiza przekrojowa (kategoryzacja). W przypadku wszystkich rodzajów gier, w których wysokość wygranych jest praktycznie nieograniczona, klasyfikowane są one jako gry wysokohazardowe. Należą do nich gry urządzane w kasynach, tj. gry cylindryczne, gry w karty i gry w kości, gry na automatach (mogą być urządzane w kasynie gry lub salonie gier na automatach) oraz gry bingo pieniężne - urządzane w salonie gry bingo pieniężne. Dodatkowo do gier wysokohazardowych zaliczane są zakłady wzajemne, które przyjmowane są wyłącznie w punktach zakładów wzajemnych. Do gier niskohazardowych zaliczane są gry na automatach o niskich wygranych. Mogą być urządzane wyłącznie w punktach gier na automatach o niskich wygranych. W przypadku tych gier wartość jednorazowej wygranej nie może być wyższa niż równowartość 15 euro, a wartość maksymalnej stawki za udział w jednej grze nie może być wyższa niż 0,07 euro - art. 2 ust. $2 b$ ustawy z dnia 29 lipca 1992 r. o grach i zakładach wzajemnych (Dz.U. z 2004 r. nr 4, poz. 27 z późn. zm.).

Liczba podmiotów działających na rynku hazardu zmieniała się i wykazywała tendencję rosnącą z 63 do 75. Główną metodą przyjętą do realizacji postawionego celu było wykorzystanie danych rzeczywistych. Podstawowe materiały źródłowe pochodziły z Ministerstwa Finansów, ponadto skorzystano z ogólnie dostępnych danych statystyki masowej.

\section{Charakterystyka istotnych właściwości branży hazardu}

Ustawowy przywilej prowadzenia działalności dawał poszczególnym podmiotom możliwość racjonalnego podejmowania decyzji w zakresie urządzania różnych rodzajów gier. Na rysunku 1 (wykres obrazkowy) przedstawiono indywidualne cechy badanych grup przedsiębiorstw wysokiego i niskiego hazardu. Poszczególnym cechom twarzy przypisano zmienne opisane w legendzie. Wykres obrazkowy przedstawia wybrane cechy badanych podmiotów (na podstawie średnich wartości wybranych zmiennych opisujących badaną populację). Celem konstruowania wykresów obrazkowych jest eksploracyjna analiza danych, która pozwala na określenie niejednorodności badanych grup oraz wykrycia istotnych zależności między zmiennymi. Różnice w wyglądzie obu twarzy Chernoffa wskazują na znaczące różnice między przedsiębiorstwami świadczącymi usługi niskiego i wysokiego hazardu.

Zróżnicowanie między dwoma grupami przedsiębiorstw w podziale na niski i wysoki hazard ze względu na zysk ze sprzedaży, wartości wygranych, rentowność i bieżącą płynność finansową oszacowano przy wykorzystaniu testu nieparametrycznego U Manna-Whitneya (Wilcoxona) [Dobosz 2004, s. 69]. W celu 


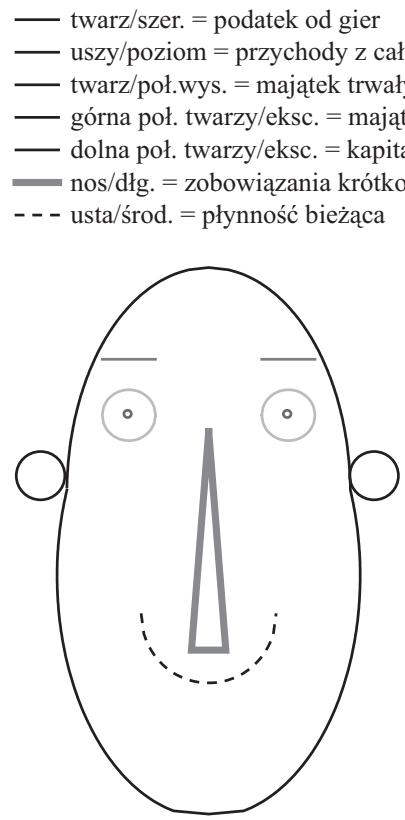

Grupa 1

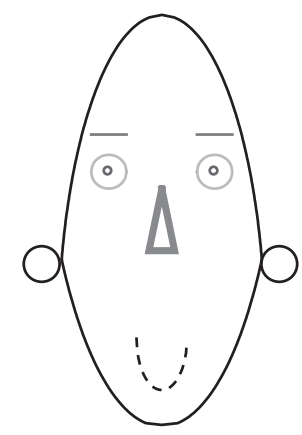

Grupa 2

\section{Rysunek 1}

Twarze Chernoffa

Źródło: Opracowanie własne.

weryfikacji przyjęcia bądź odrzucenia określonej hipotezy posłużono się testami nieparametrycznymi, z uwagi na brak spełnienia hipotezy o normalności rozkładu dla opisywanych zmiennych. W sytuacji prowadzenia przez dany podmiot więcej działalności, wykluczono z badań działalność podobną (takich obserwacji było $31 \mathrm{w}$ badanym okresie). Test U Manna-Whitneya przeprowadzono w celu identyfikacji zróżnicowania poziomów rentowności i płynności finansowej. Test ten jest nieparametrycznym odpowiednikiem analizy wariancji, w którym sformułowane hipotezy są następujące:

- $H_{0}$ : Dystrybuanty wybranych zmiennych w dwóch grupach podmiotów maja taki sam rozkład,

- $H_{1}$ : Dystrybuanty wybranych zmiennych w dwóch grupach podmiotów nie mają takiego samego rozkładu.

Test ten wykonywany jest w oparciu o sumę rang, a nie średnich, porównując mediany dwóch prób niezależnych [Stanisz 2006, s. 372]. W tabeli 1 przedstawiono wyniki testu U Manna-Whitneya dla badanych podmiotów w latach 2006-2008. 
Tabela 1

Test U Manna-Whitneya według typu działalności

\begin{tabular}{|l|c|c|c|c|}
\hline Wyszczególnienie & $\mathrm{U}^{\mathrm{a}}$ & $\mathrm{P}^{\mathrm{b}}$ & Z skorygowane $^{\mathrm{c}}$ & $\mathrm{P}^{\mathrm{d}}$ \\
\hline Zysk/strata na sprzedaży & 0,4045 & 0,6858 & 0,40451 & 0,6858 \\
\hline Wartość wygranych & 3,1149 & 0,0018 & 3,11496 & 0,0018 \\
\hline ROE & $-1,7636$ & 0,0778 & $-1,76360$ & 0,0778 \\
\hline ROA & $-3,0261$ & 0,0024 & $-3,02608$ & 0,0024 \\
\hline ROS & $-0,9559$ & 0,3391 & $-0,95587$ & 0,3391 \\
\hline Bieżąca płynność finansowa & $-2,2235$ & 0,0261 & $-2,22350$ & 0,0261 \\
\hline
\end{tabular}

a Wartość testu U Manna-Whitneya dla liczebności obu grup powyżej 20 przypadków.

${ }^{b}$ Poziom istotności obliczony dla wartości testu U Manna-Whitneya dla liczebności obu grup powyżej 20 przypadków.

${ }^{c}$ Wartość testu U Manna-Whitney, skorygowana ze względu na przyporządkowane rangi dla liczebności obu grup powyżej 20 przypadków.

d Poziom istotności obliczony dla skorygowanej wartości testu U Manna-Whitneya.

Źródło: Opracowanie własne.

Na podstawie poziomu istotności, którego poziom był poniżej $\mathrm{p}=0,05$, odrzucono hipotezę zerowa, co potwierdziło istotne różnice statystyczne badanych grup przedsiębiorstw ze względu na wartość wygranych, rentowność aktywów ogółem i bieżącą płynność finansową (wyniki te potwierdzono testem Kołmogorowa-Smirnowa, który również testuje zróżnicowanie między dwoma grupami przedsiębiorstw przy założeniu, że są one z różnych populacji). Wartość testu U Manna-Whitneya nie znajdowała się w obszarze krytycznym. Dla zmiennych zysk/strata ze sprzedaży, ROE oraz ROS nie odnotowano istotnego zróżnicowania między badanymi grupami przedsiębiorstw dla założonego poziomu istotności równego 0,05 . Wartość testu U Manna-Whitneya dla tych zmiennych była wyższa od wartości krytycznej, zatem nie było podstaw do odrzucenia hipotezy zerowej [Stanisz 2006, s. 378].

Ze skategoryzowanego obrazu ramka-wąsy w ramach grup przedsiębiorstw, skumulowanego dla 3 lat badanego okresu (rys. 2) wynika, że wskaźnik rentowności sprzedaży ROS największe zróżnicowanie w całym obszarze zmienności wykazał w grupie 1 . Dla tej grupy wystąpiło również większe zróżnicowanie dla $50 \%$ środkowych podmiotów (dłuższa skrzynka) niż to miało miejsce w przypadku grupy 2 . W grupie spółek wysokiego hazardu mamy do czynienia z symetrycznym rozkładem - rysunek 2 . W przypadku rentowności kapitału własnego wystąpiła wyraźna symetryczność w grupie 1 . Linia mediany leży dokładnie w środku skrzynki, a oba wąsy są zbliżonej długości. Oznacza to, że rozkład jest symetryczny zarówno w całym obszarze zmienności, jak i 50\% środkowych podmiotów. W grupie 2 stwierdzono największe zróżnicowanie ze względu na rentowność kapitałów własnych - rysunek 3. 


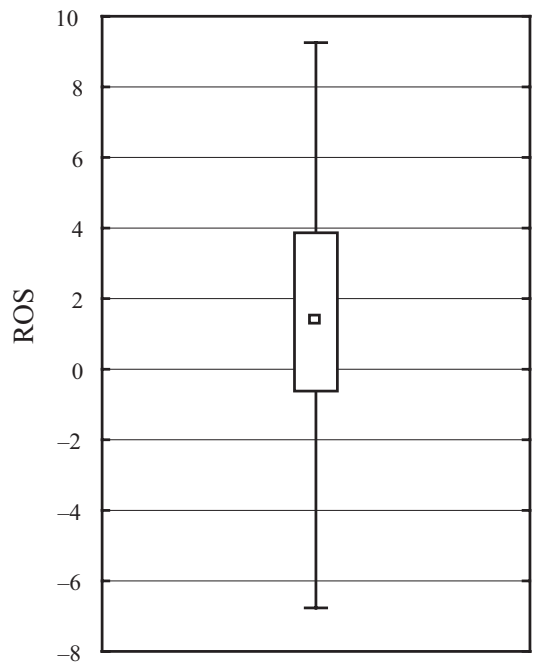

Grupa: 1

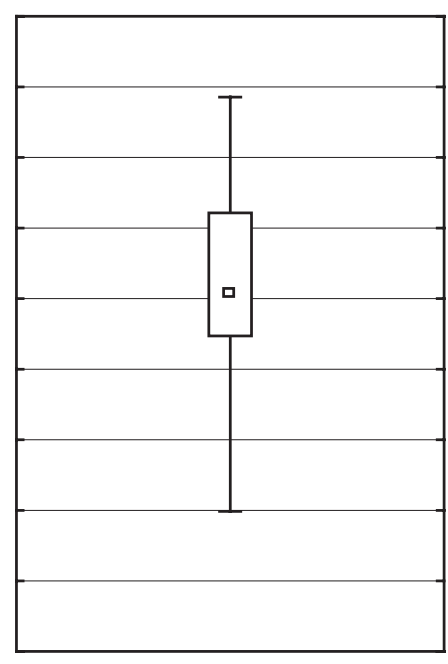

Grupa: 2
․ Mediana

I Zakres nieodstających

\section{Rysunek 2}

Ramka-wąsy w porównaniu z rentownością sprzedaży [\%]

Źródło: Opracowanie własne.
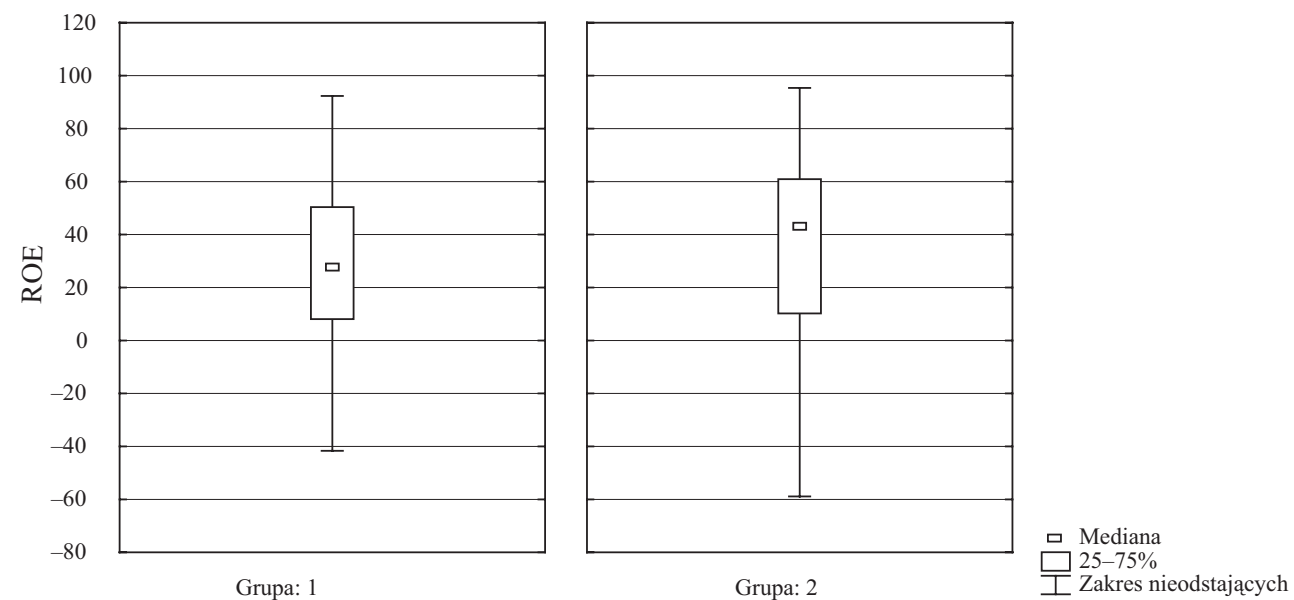

Rysunek 3

Ramka-wąsy w porównaniu z rentownością kapitału własnego [tys. zł] Źródło: Opracowanie własne. 
W grupie 2 zaobserwowano bardzo znaczące zróżnicowanie ze względu na wskaźnik bieżącej płynności. Górny wąs wskazuje na asymetrię rozkładu w całym obszarze zmienności i dla 50\% środkowych jednostek. Znacznie mniejsze zróżnicowanie wykazuje grupa 1 . Wystąpił w niej symetryczny rozkład dla 50\% środkowych spółek - rysunek 4.

W tabeli 2 przedstawiono wartości średnie, mediany oraz odchylenia standardowego dla grupy przedsiębiorstw zajmujących się jedynie świadczeniem usług z zakresu niskiego hazardu. Zmienna podatek od gier charakteryzowała się wartością mediany znacząco poniżej średniej arytmetycznej w całym badanym okresie. Wraz ze zwiększeniem wartości mediany w latach 2006-2008 odnotowano wzrost odchylenia standardowego. Przyczyniło się to do zwiększenia wielkości wskaźnika zmienności (relacja odchylenia standardowego do średniej), która wynosiła odpowiednio $147,6,155,5$ oraz $164,1 \%$.

Zróżnicowanie zakresu obserwacji w badanym okresie dla zmiennej ,podatek od gier" przedstawiono na rysunku 5. Znacząca zmienność podatku od gier $\mathrm{w}$ badanej grupie wynika z różnorodności w skali prowadzonej działalności, co odzwierciedla zróżnicowana liczba automatów w danych podmiotach. Średnia liczba automatów wynosiła w latach 2006-2008 odpowiednio 485, 588, i 638, a mediana tej wielkości kształtowała się na poziomie niższym, który wyniósł odpowiednio 203, 240,244. Wielkość ta odnotowała nieznaczny wzrost w badanym okresie, zwiększyła się zaś średnia liczba automatów w badanych pod-
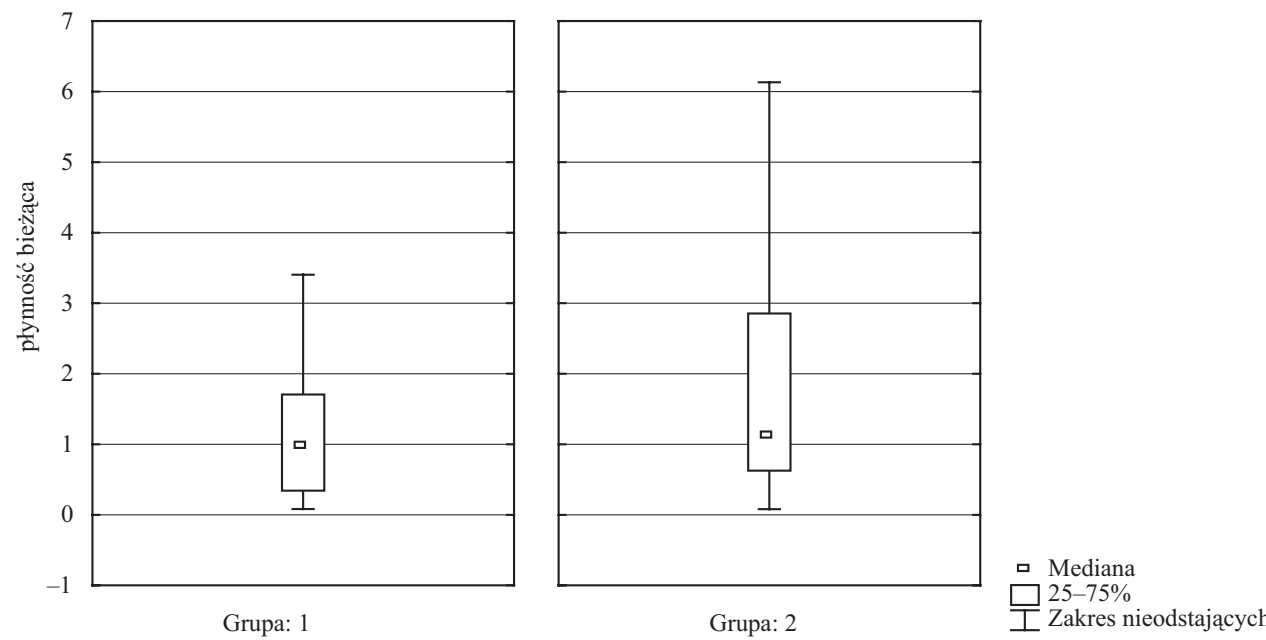

\section{Rysunek 4}

Ramka-wąsy w porównaniu z płynnością bieżąca [tys. zł]

Źródło: Opracowanie własne. 
Tabela 2

Miary położenia zmiennych dla podmiotów z automatami o niskich wygranych

\begin{tabular}{|l|c|c|c|c|c|c|c|c|c|}
\hline \multirow{2}{*}{$\begin{array}{l}\text { Wyszcze- } \\
\text { gólnienie }\end{array}$} & \multicolumn{9}{|c|}{ Lata } \\
\cline { 2 - 11 } & $\bar{X}$ & $\mathrm{IIQ}$ & $\sigma$ & $\bar{X}$ & $\mathrm{IIQ}$ & $\sigma$ & $\bar{X}$ & $\mathrm{IIQ}$ & $\sigma$ \\
\hline $\begin{array}{l}\text { Podatek } \\
\text { od gier } \\
\text { [tys. zł] }\end{array}$ & 2927,6 & 1211,0 & 4321,3 & 3331,2 & 1352,5 & 5179,6 & 4974,9 & 2167,0 & 8165,7 \\
\hline $\begin{array}{l}\text { Liczba } \\
\text { automatów }\end{array}$ & 485,3 & 203,0 & 724,0 & 588,3 & 240,0 & 928,5 & 638,6 & 244,0 & 1085,4 \\
\hline $\begin{array}{l}\text { Zysk/strata } \\
\text { netto } \\
\text { [tys. zł] }\end{array}$ & 2149,9 & 869,0 & 4151,6 & 4215,7 & 1719,7 & 6406,6 & 4358,7 & 1924,6 & 6277,2 \\
\hline $\begin{array}{l}\text { Kapitał } \\
\text { własny } \\
\text { [tys. zł] }\end{array}$ & 4351,9 & 2398,5 & 7846,6 & 7914,5 & 3517,2 & 13632,2 & 8013,6 & 3411,1 & 10531,0 \\
\hline ROE [\%] & 26,7 & 44,5 & 51,0 & 41,5 & 48,0 & 34,5 & 40,6 & 43,1 & 26,2 \\
\hline ROA [\%] & 21,7 & 24,7 & 26,6 & 29,8 & 27,4 & 27,5 & 24,1 & 23,5 & 19,1 \\
\hline ROS [\%] & 2,8 & 2,2 & 5,4 & 3,1 & 2,9 & 5,7 & 2,6 & 2,2 & 2,7 \\
\hline $\begin{array}{l}\text { Płynność } \\
\text { bieżaca } \\
\text { (krotność) }\end{array}$ & 2,8 & 1,5 & 2,8 & 3,6 & 1,7 & 5,0 & 1,8 & 0,9 & 2,4 \\
\hline
\end{tabular}

$\bar{X}$ - wartość średnia, $\Pi \mathrm{Q}$ - mediana, $\sigma$ - odchylenie standardowe.

Źródło: Opracowanie własne.

miotach i odchylenie standardowe, które w 2008 roku wynosiło 1085,4. Świadczy to o pogłębiającym się zróżnicowaniu w badanej populacji, polegającym na zwiększaniu liczby automatów w największych podmiotach i utrzymywaniu przez większość mniejszych podmiotów działających na rynku niskiego hazardu, automatów w tej samej zbliżonej liczbie (244 sztuk w 2008 r.). Zmienna ta, podobnie jak zmienna podatek od gier, charakteryzowała się bardzo dużą zmiennością, gdyż współczynnik zmienności w 2008 roku wyniósł 169,9\%.

Znaczną zmienność wartości odnotowano dla zmiennej zysku/straty netto, której mediana kształtowała się poniżej średniej arytmetycznej. W 2008 roku mediana dla tej pozycji zysku/straty była ponaddwukrotnie mniejsza niż średnia arytmetyczna. Świadczy to o dużej rozpiętości w generowanych zyskach w badanej grupie podmiotów.

W 2008 roku zwiększono obciążenie przedsiębiorstw świadczących usługi niskiego hazardu. W celu potwierdzenia istotności zwiększenia obciążenia tych przedsiębiorstw w 2008 roku w stosunku do lat 2006-2007 przeprowadzono test 


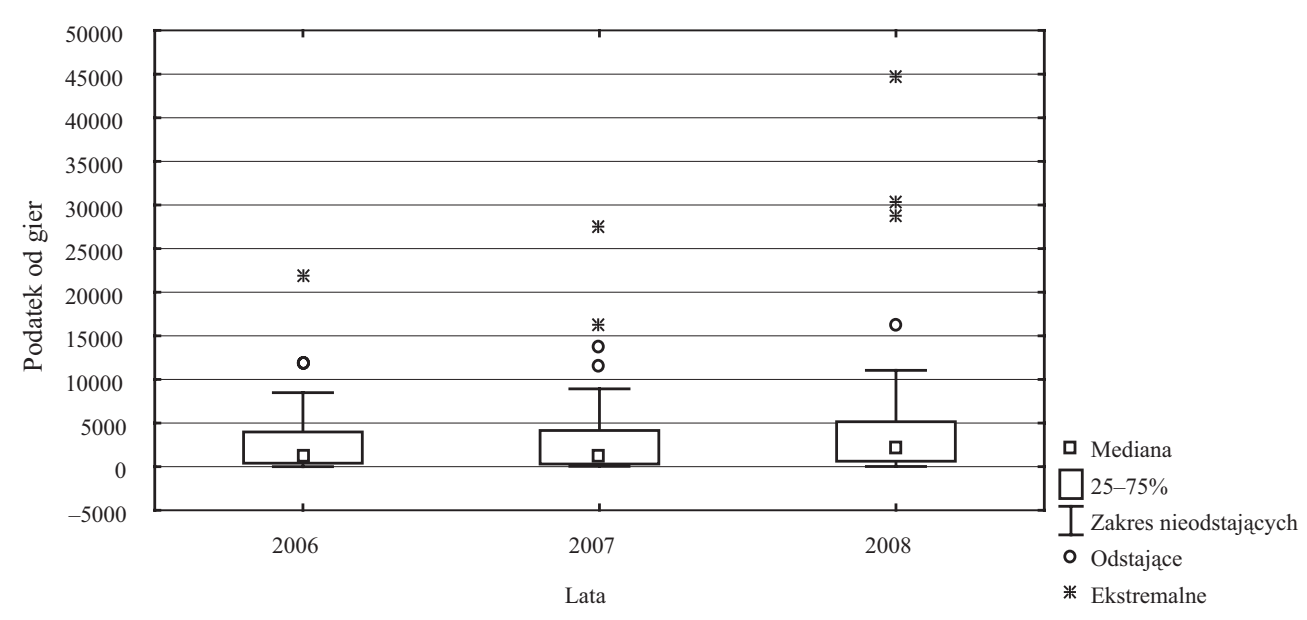

\section{Rysunek 5}

Ramka-wąsy dla zmiennej podatek od gier [tys. zł]

Źródło: Opracowanie własne.

kolejności par Wilcoxona ${ }^{1}$. Test ten potwierdził istotne statystycznie zróżnicowanie obciążenia podatkiem od gier przedsiębiorstw świadczących usługi niskiego hazardu $\left(\mathrm{n}=137, \mathrm{~W}=0,9894^{2}\right.$ dla $\left.\mathrm{p}=0,0000^{3}\right)$.

Na rysunku 6 przedstawiono miary pozycyjne dla zmiennej zysk/strata netto, na którym stwierdzono dużą liczbę obserwacji odstających i ekstremalnych, która zwiększyła swą liczebność szczególnie w 2008 roku, mimo zwiększenia stawek ,,podatku od gier”.

Zbliżoną tendencję w zakresie sytuacji finansowej badanych podmiotów odnotowano dla zmiennej kapitał własny, którego mediana w badanym okresie odnotowała niższy poziom w relacji do średniej wartości tego kapitału własnego (rys. 7).

Różnica ta zwiększyła się znacząco w badanym okresie, gdyż wartość mediany w 2008 roku w relacji do średniej wynosiła 43,6\%, wobec 55,2\% w 2006 roku. Odchylenie standardowe w badanej populacji zmiennej kapitał własny było największe w 2007 roku i wyniosło 12 632,2 tys. zł. Świadczy to o bardzo dużym zróżnicowaniu wyposażenia w kapitał własny w badanych podmiotach.

\footnotetext{
${ }^{1}$ Test Wilcoxona został zastosowany do porównania wartości podatku od gier między latami 2006-2007 a 2008 rokiem w odniesieniu do zmiennych powiązanych i z powodu braku normalności rozkładu tej zmiennej (nie można było zastosować testu t-Studenta).

${ }^{2}$ Wartość testu Wilcoxona dla grup o liczebności $n>25$.

${ }^{3}$ Poziom prawdopodobieństwa testowego p dla testu Wilcoxona.
} 


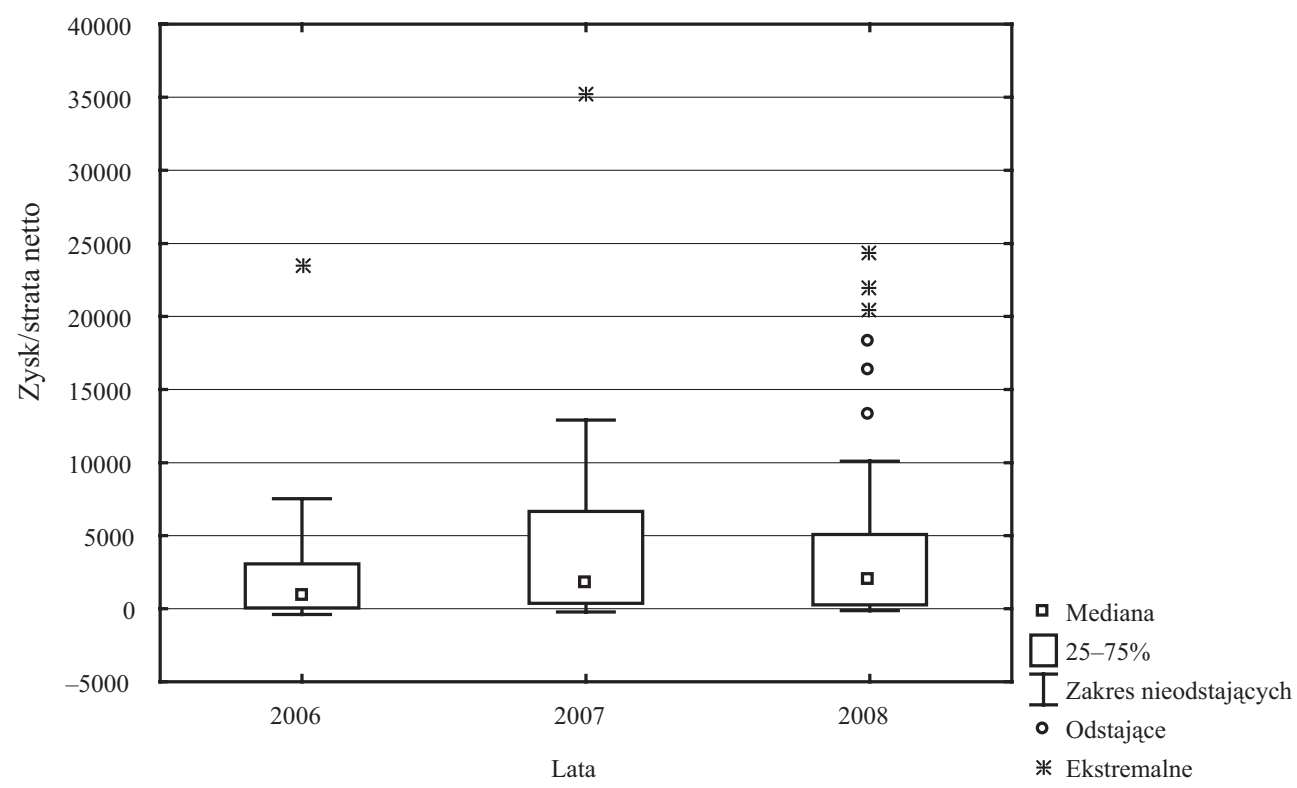

\section{Rysunek 6}

Ramka-wąsy dla zmiennej zysk/strata netto [tys. zł]

Źródło: Opracowanie własne.

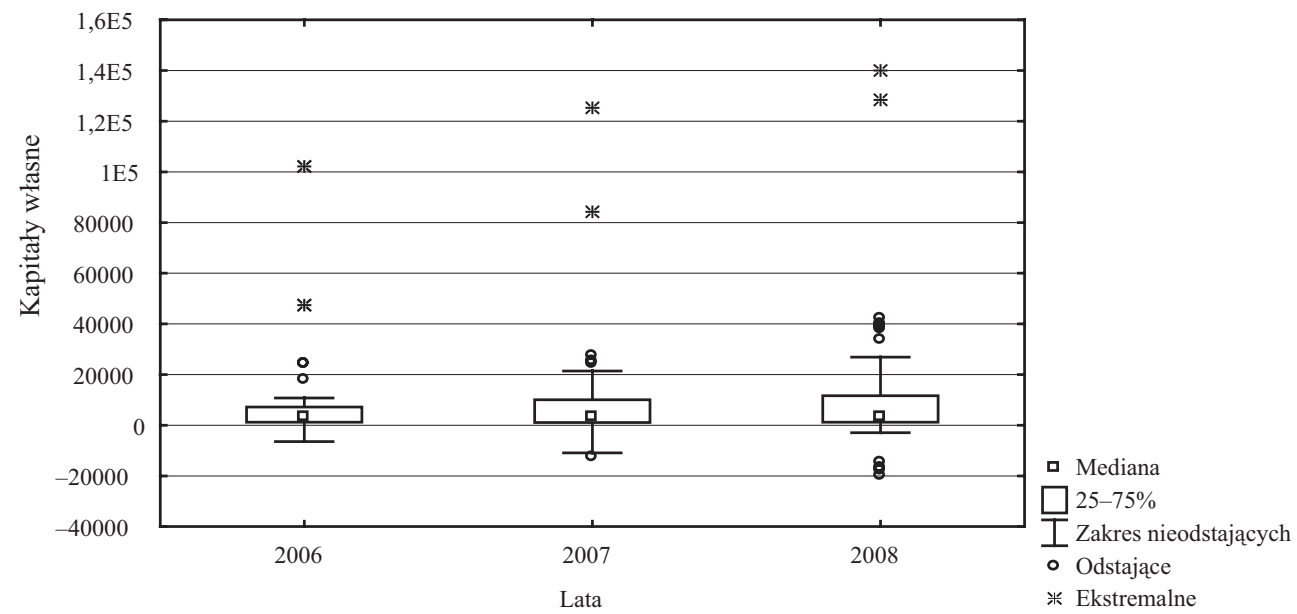

\section{Rysunek 7}

Ramka-wąsy dla zmiennej kapitał własny [tys. zł]

Źródło: Opracowanie własne. 
Wskaźnik rentowności kapitału własnego charakteryzował się większą wielkością mediany niż średnia w badanym okresie, a różnica między tymi wielkościami zmniejszała się (rys. 8). W celu prezentacji danych na wykresie pominięto wielkości ekstremalne. Najwyższy poziom mediany odnotowano w 2007 roku, który wyniósł $48 \%$ przy średniej na poziomie $41,5 \%$. Ponadto stwierdzono również tendencję spadku odchylenia standardowego dla tego wskaźnika, gdyż w 2006 roku odchylenie to wynosiło 51 p.p. wobec 26,2 p.p. w 2008 roku. Świadczy to o zmniejszającym się zróżnicowaniu rentowności kapitału własnego w badanej grupie podmiotów pomimo różnic w skali działalności.

Rentowność aktywów ogółem badanej grupy podmiotów odnotowała zbliżony poziom mediany i średniej arytmetycznej w badanym okresie. Mediana dla tego wskaźnika była większa jedynie w 2006 roku od średniej (wynosiła 24,7\% wobec $21,7 \%$ wielkości średniej). W pozostałych latach wartość mediany była nieznacznie mniejsza. Ponadto $w$ badanym okresie odnotowano spadek odchylenia standardowego ROA w 2008 roku w stosunku do 2006 roku (z 26,6 do 19,1 p.p.).

Na rysunku 9 przedstawiono poziom rentowność aktywów ogółem badanej grupy podmiotów w latach 2006-2008. Dla celów prezentacji danych na rysunku pominięto wielkości ekstremalne.

Rentowność sprzedaży charakteryzowała się mniejszą wartością mediany niż średniej arytmetycznej, a różnica ta wynosiła od 0,2 p.p. w 2006 roku do 0,4 p.p. w 2008 roku. W badanym okresie stwierdzono również spadek odchylenia standardowego tego wskaźnika w 2006 roku, z poziomu 5,4 do 2,7 p.p.

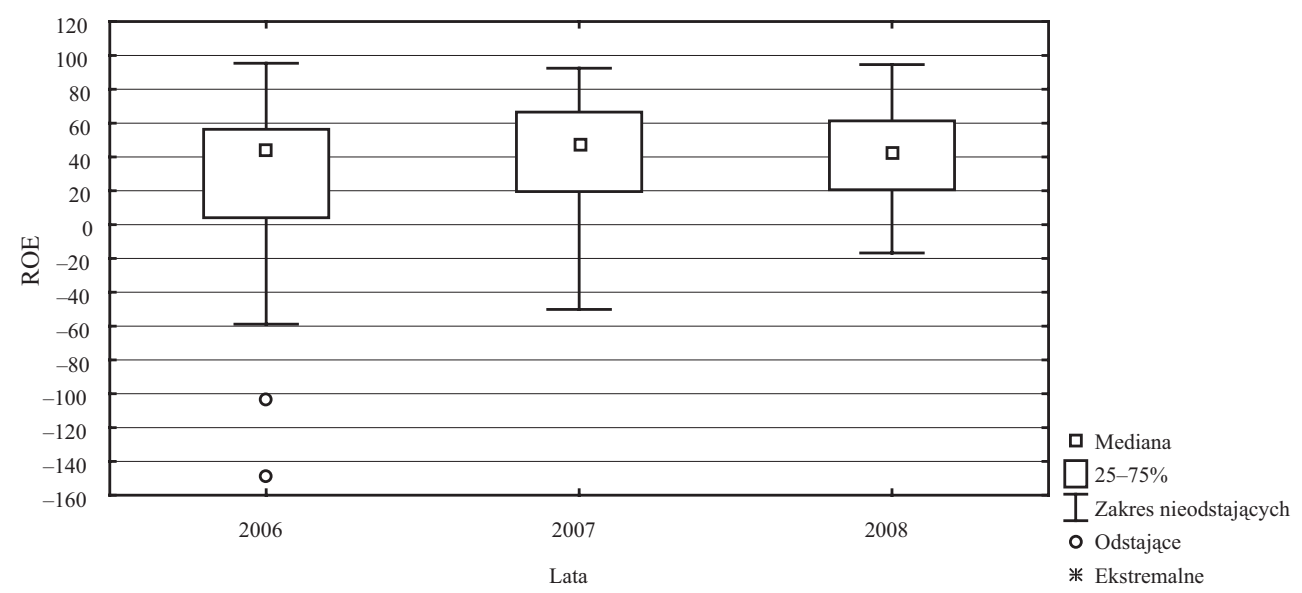

Rysunek 8

Ramka-wąsy dla zmiennej rentowność kapitału własnego ROE [\%]

Źródło: Opracowanie własne. 
w 2008 roku. Tendencja zmian w tym zakresie jest zbliżona do wskaźnika rentowności kapitału własnego. Na rysunku 10 przedstawiono poziom rentowności sprzedaży badanej grupy podmiotów w latach 2006-2008. Dla celów prezentacji danych na wykresie pominięto część wielkości ekstremalnych.

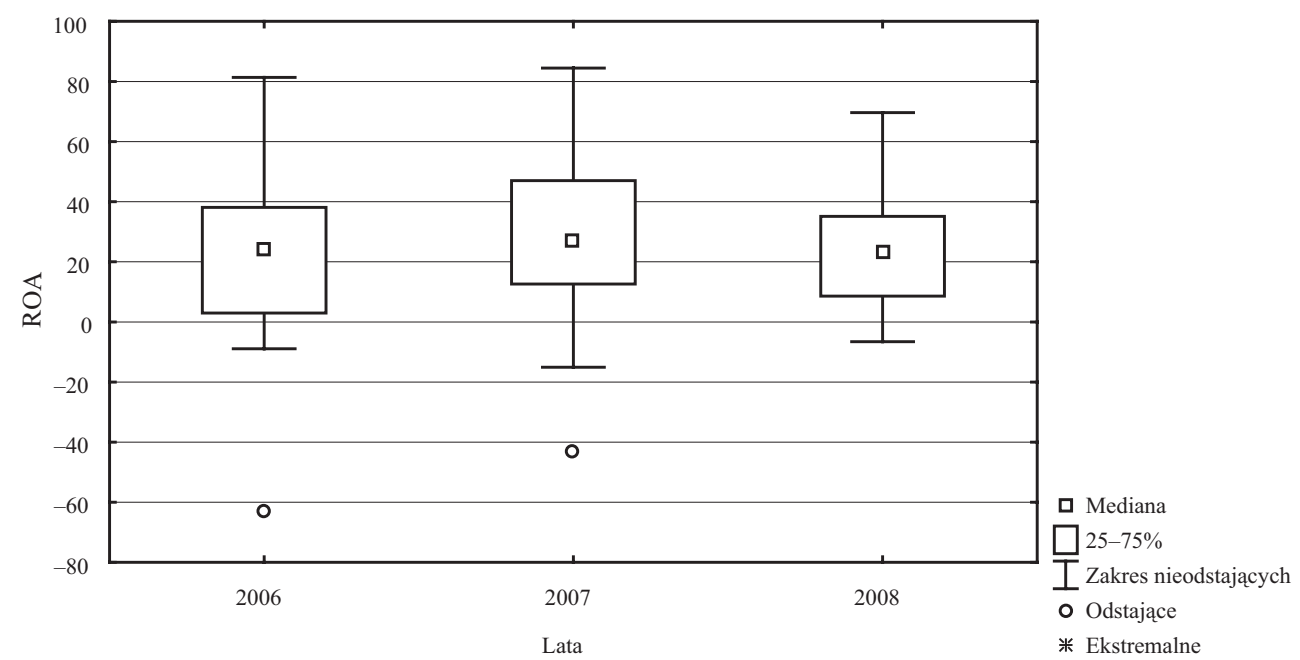

\section{Rysunek 9}

Ramka-wąsy dla zmiennej rentowność aktywów ogółem (ROA) [\%]

Źródło: Opracowanie własne.

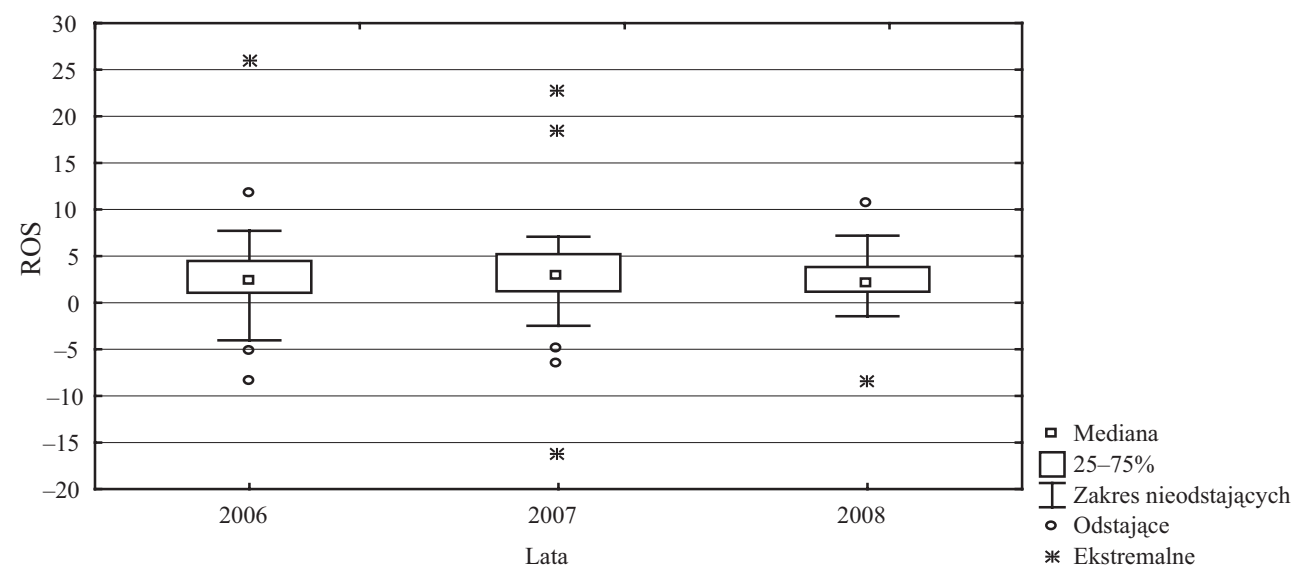

\section{Rysunek 10}

Ramka-wąsy dla zmiennej rentowność sprzedaży (ROS) [\%]

Źródło: Opracowanie własne. 


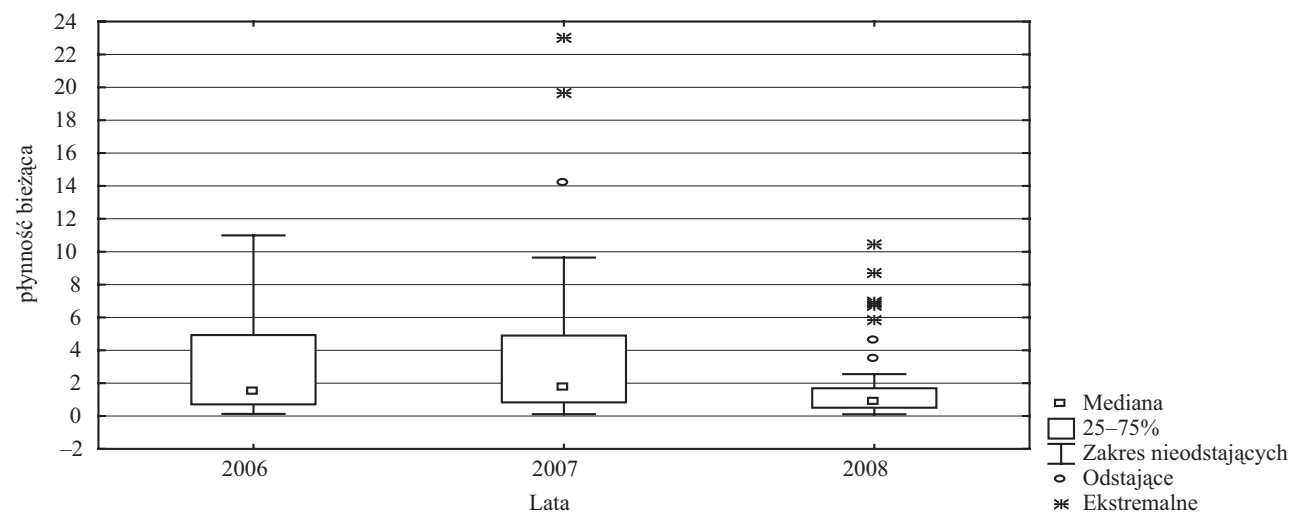

Rysunek 11

Ramka-wąsy dla zmiennej bieżąca płynność finansowa [krotność]

Źródło: Opracowanie własne.

Wskaźnik bieżącej płynności finansowej w badanej grupie podmiotów odnotował niższy poziom mediany od wielkości średniej. Świadczy to o większym zróżnicowaniu w zakresie wykorzystania krótkoterminowych źródeł finansowania w badanym podmiotach w relacji do wskaźników rentowności. Największe zróżnicowanie w zakresie płynności bieżącej stwierdzono w 2008 roku, w którym poziom mediany znacząco spadł (w porównaniu z 2006 r. z 1,5 do 0,9), i był o $50 \%$ niższy od wielkości średniej w badanej grupie podmiotów $(1,8)$. Ponadto w roku tym stwierdzono spadek wielkości odchylenia standardowego, które kształtowało się na poziomie 2,4 wobec 2,8 w 2006 roku i 5,0 w 2007 roku. Na rysunku 11 przedstawiono rozkład obserwacji dla zmiennej „płynność bieżąca” w badanym okresie. Stwierdzono znaczący przyrost obserwacji zarówno odstających, jak i ekstremalnych w ostatnim roku badawczym. Świadczy to o bardzo dużym zróżnicowaniu w zakresie utrzymywanej bieżącej płynności finansowej w 2008 roku, co wiązało się ze znaczącym spadkiem jej poziomu w całej badanej populacji przedsiębiorstw.

\section{Wnioski}

Na rynku hazardu w analizowanym okresie wystąpiło wyraźne zróżnicowanie między dwoma grupami przedsiębiorstw, tj. niskiego i wysokiego hazardu. W szczególności zauważalne to było w przypadku takich kategorii, jak: podatek od gier, bieżąca płynność finansowa, zobowiązania krótkoterminowe, majątek 
trwały i majątek obrotowy oraz kapitały własne. Prezentują się one korzystniej w grupie spółek wysokiego hazardu.

Stwierdzono istotne różnice statystyczne badanych grup przedsiębiorstw ze względu na wartość wygranych, rentowność aktywów ogółem i bieżącą płynność finansową.

Dla zmiennych zysk/strata ze sprzedaży, ROE oraz ROS nie odnotowano istotnego zróżnicowania między badanymi grupami przedsiębiorstw dla założonego poziomu istotności 0,05 .

Bardzo duża zmienność podatku od gier w grupie spółek niskiego hazardu wynikała $\mathrm{z}$ różnorodności w skali prowadzonej działalności, co odzwierciadlała zróżnicowana liczba automatów w danych podmiotach. W 2008 roku stwierdzono pogłębiające się zróżnicowanie polegające na zwiększaniu liczby automatów w największych podmiotach i utrzymywaniu przez większość mniejszych spółek działających na rynku niskiego hazardu automatów w zbliżonej liczbie 244 sztuk. Konsekwencją takiego stanu rzeczy była duża rozpiętość w generowanych zyskach osiąganych przez spółki niskiego hazardu.

\section{Literatura}

DOBOSZ M., 2004: Statystyczna analiza wyników badań, Akademicka Oficyna Wydawnicza EXIT, Warszawa.

STANISZ A., 2006: Przystępny kurs statystyki z zastosowaniem STATISTICA PL na przykładach z medycyny, tom 1, Statystyki Podstawowe. Wydawnictwo Statsoft, Kraków.

Informacja o realizacji ustawy o grach i zaktadach wzajemnych za lata 2006-2008, Ministerstwo Finansów, Warszawa.

PUŁASKA-TURYNA B., 2005: Statystyka dla ekonomistów, Difin, Warszawa.

ADAMCZAK H., 1996: Statystyka, zastosowania w ekonomii: Analiza struktury zbiorowości statystycznej, szeregów czasowych oraz wspólzależności zjawisk, Ośrodek Doradztwa i Doskonalenia Kadr, Gdańsk.

JÓŹWIAK J., 1992: Statystyka od podstaw. Państwowe Wydawnictwa Ekonomiczne, Warszawa.

WALCZAK M., 2007: Analiza finansowa w zarządzaniu współczesnym przedsiębiorstwem, Difin, Warszawa.

POMYKALSKA B., POMYKALSKI P., 2007: Analiza finansowa przedsiębiorstwa, Wydawnictwo Naukowe PWN, Warszawa.

BIK M., KAMIONOWSKI R., OBRĘPALSKI D., RYSZARD K., 2012: Gry hazardowe. Komentarz do ustawy o grach hazardowych, Difin, Warszawa. 


\title{
Factors affecting financial position of enterprises of gambling - statistical survey
}

\begin{abstract}
The purpose of the article was to present, basing on the measurement and statistical analysis, essential characteristics of the games and betting industry in Poland. Particular importance was given to the differences between games with low and high winnings, as well as revealing economic conditions having impact on the financial situation of enterprises of gambling. In the analyzed period 2006-2008 there was a clear differentiation between the two groups of companies, i.e. with low and high winnigs. Such categories as: gaming tax, current liquidity, liabilities, assets and rotating and equity seem to be significantly better in the group of companies offering high winnings.
\end{abstract}

